\title{
The Relationship of Knowledge of The Covid and Prevention Protocol In Students of SDIT Al-Madinah To Compliance With The Covid and Prevention Protocol
}

\author{
Wuri Utami, Nurlaila, Ning Iswati \\ STIKES Muhammadiyah Gombong, Indonesia \\ Corresponding author: utamiwuri@gmail.com
}

\begin{abstract}
Background: The health problem that is currently in the spotlight and attention of the world is the Covid-19 disease. Covid-19 disease not only affects adults, but also affects children. The American Centers for Disease Control and Prevention (CDC) report shows that children and adolescents are more at risk for complications related to COVID-19. From the data collected from February to July 2020, it was found that $70 \%$ of the 121 cases of children and adolescents who died from diseases related to Covid-19 were aged 10-20 years.

Purpose: This study aimed to determine the knowledge of the Covid 19 prevention protocol in SDIT Al students. Medina Against Compliance with Covid 19 prevention protocols.

Methods: Quantitative research methods, correlational design, sample size 270 classes 4,5,6 at SDIT Al. Medina Kebumen. Quantitative research method, correlational design, sample size 270 grades 4,5,6 in SDIT Al. Medina Kebumen. Data analysis used statistical test with chi-square test.

Results: The results showed that 131 respondents $(70.8 \%)$ had good knowledge of the covid 19 prevention protocol for SDIT Al Madinah students, 168 respondents (90.8\%) were obedient.

Conclusion: Research analysis shows that there is a relationship between knowledge of the covid 19 prevention protocol in SDIT Al Madinah students and adherence to the covid 19 prevention protocol. $(\mathrm{p}=.000<0.05)$.
\end{abstract}

Keywords: Knowledge, Covid, Prevention Protocol, Student. 
Journal Of Nursing Practice

http://thejnp.org

ISSN: 2614-3488 (print); 2614-3496 (online)

Vol.5 No.1. October 2021. Page.89-93

\section{BACKGROUND}

In Indonesia, the number of COVID-19 cases is increasing from time to time, so the Covid-19 emergency situation is enforced in Indonesia. In connection with the increase in cases of transmission of Covid 19, it is necessary to take steps to prevent transmission by complying with the protocol for preventing transmission of Covid 19 (Mendes RI, 2020). Knowledge about the Covid-19 disease is very important so as not to cause an increase in the number of Covid-19 cases. Knowledge of Covid-19 patients can be interpreted as a result of knowing from patients about their disease, understanding their disease, ways of prevention, treatment and complications (Sari \& Atiqoh, 2020).

WHO advises how to prevent the transmission of Covid 19 by diligently washing hands with soap in running water, keeping a distance from people when talking, not touching your face with dirty hands. It is also recommended to wear a mask and cover the nose and mouth with a tissue or bent elbow when coughing (WHO, 2020). There are several steps to prevent the spread of COVID-19 conveyed by the Ministry of Health, namely: (a) always carry out hand hygiene by using a hand sanitizer or washing hands using soap in running water, (b) do not touch the mouth, eyes or nose, (c) practice cough and sneeze etiquette mainly in public places (d) use a mask when leaving the house, (e) apply the principle of keeping a distance (at least 1 meter) (Ministry of Health, 2020).

The government has announced a learning activity scheme during face-to-face implementation with strict health protocols, therefore several elementary schools have started to apply face-to-face learning by applying alternate schedules of at least $50 \%$ of the total number of students attending with a meeting duration of only 4 hours. Based on the situation above, it is necessary to have sufficient knowledge about the Covid 19 prevention health protocol from students, so that it does not cause concern from parents or other school residents during the face-to-face learning process.

SDIT Al. Medina is one of the SDITs in Kebumen district that implements education with a not only cognitive approach but emphasizes soft skills to Islam, so that direct face-to-face teaching is always attempted in the midst of this Covid 19 pandemic, although it must be limited to the number in one study group. The Covid 19 protocol has been implemented by the school, but based on the phenomenon there are still students who have not been able to comply with the regulations that have been implemented, including students who share food supplies with each other and take off masks when they are tired. This kind of behavior can influence other students to disobey as well

The results of interviews with several students in grades 4,5,6 said that they did not yet understand the knowledge about the Covid 19 prevention protocol. Thus, researchers needed to examine the knowledge of the students of SDIT Al. Medina about the Covid 19 prevention health protocol on compliance with the Covid 19 prevention health protocol.

\section{METHODS}

This research method is using quantitative research methods with analytical correlational research with a cross sectional approach. This research was conducted offline with the application of health protocols on April 28, 2021 - May 13, 2021 by providing a form containing a questionnaire. The place of this research is SDIT Al. Medina.

The population in this study were students of grade 4,5,6 SDIT Al Madinah in Kebumen totaling 185. Sampling used consecutive sampling.

The inclusion criteria in this study were 4,5,6 grade elementary school students who had obtained permission from their guardians to participate in the study by signing a letter of consent. 


\section{Journal Of Nursing Practice}

http://thejnp.org

ISSN: 2614-3488 (print); 2614-3496 (online)

Vol.5 No.1. October 2021. Page.89-93

This research instrument uses a knowledge questionnaire of the covid 19 prevention protocol and compliance with the covid 19 prevention protocol. Data analysis used was univariate analysis in the form of frequency distribution and bivariate analysis using chi-square test. This research has received a letter of passing the ethical test from STIKES Muhammadiyah Gombong.

\section{RESULTS}

\section{Univariate Analysis Results}

a. Knowledge of covid 19 prevention protocols

Distribution of the frequency of knowledge on covid 19 prevention protocols at SDIT Al Madinah, Kebumen Regency in 2021 ( $\mathrm{n}=185)$

Based on the frequency distribution of knowledge of the covid 19 prevention protocol, it is known that most of the knowledge of the covid 19 prevention protocol of SDIT Al Madinah students as many as 131 respondents $(70.8 \%)$ is good.

b. Covid-19 prevention protocol compliance

Distribution of Covid 19 Prevention Protocol Compliance at SDIT Al Madinah, Kebumen Regency in $2021(\mathrm{n}=185)$.

Based on the frequency distribution of compliance with the covid 19 prevention protocol, it is known that most of the compliance with the covid 19 prevention protocol of SDIT Al Madinah students as many as 168 respondents (90.8\%) were compliant.

\section{Results of Bivariate Analysis}

a. The Relationship between Knowledge of the Covid 19 Prevention Protocol for SDIT A1 Madinah Students to the Compliance of the Covid 19 Prevention Protocol in Kebumen Regency in 2021 (=185).

Based on the results of the analysis, it is known that the Asymp value. Sig. (2-tailed) of 0.001 due to Asymp. Sig $0.001<0.05$, then according to the basis of decision making in the Chi Square test, it can be concluded that Ho is rejected. Rejection of Ho implies that there is a significant relationship between knowledge of the covid 19 prevention protocol in SDIT Al Madinah students and adherence to the covid 19 prevention protocol.

\section{DISCUSSION}

\section{Univariate Variables}

a. Knowledge of covid 19 prevention protocols

Based on the results of the study, it was found that most of the knowledge of the covid 19 prevention protocol of SDIT Al Madinah students as many as 131 respondents $(70.8 \%)$ was good and as many as 54 respondents $(29.2 \%)$ was sufficient.

Knowledge is the result of knowing and this occurs after someone has sensed an object. Sensing occurs through the human senses, namely, the senses of hearing, sight, smell, feeling and touch. Some human knowledge is obtained through the eyes and ears (Notoadmodjo, 2012). Many factors affect a person's knowledge, including education level, mass media/information sources, environment, experience, and age (Budiman and Riyanto, 2013). The results of this study indicate that the level of knowledge of students is good about Covid-19. A good level of knowledge can be due to their age being in the range of 10-12 years, making it easier to receive various information related to COVID-19. In addition, the young age, making the ability to capture information is also getting better. The amount of information circulating in electronic media and the internet, as well as the ability to access the internet that they have makes it easier for them to access various information about Covid-19. 


\section{Journal Of Nursing Practice}

http://thejnp.org

b. Covid-19 prevention protocol compliance

Based on the results of the study, it was found that most of the compliance with the Covid 19 prevention protocol of SDIT Al Madinah students as many as 168 respondents (90.8\%) were compliant and 17 respondents $(9.2 \%)$ were non-compliant.

Compliance is a condition that is created and formed through a process of a series of behaviors that show the values of obedience, obedience, loyalty, order and order (Prijadarminto, 2011 in Mongi \& kalerat, 2017).

In this study, it was found that most of the students of SDIT Al Madinah comply with the covid 19 prevention protocol, this is influenced by the implementation of the covid 19 prevention protocol that the school applies to students who enter school and with the facilities that have been prepared before being sent to school. apply face-to-face learning by providing a handwashing area in each class and checking the temperature before entering class and being required to use masks or face shields when students are in school, this is in line with the results of Dewi (2017) research which states that compliance in supported by external factors, including the physical and non-physical environment, one of which is the regulations set by humans

\section{Bivariate Variable}

Relationship Knowledge of covid 19 prevention protocols to compliance with prevention protocols covid 19

Based on the results of the analysis, it is known that the Asymp value. Sig. (2-tailed) of 0.001 due to Asymp. Sig $0.001<0.05$, then according to the basis of decision making in the Chi Square test, it can be concluded that Ho is rejected. Rejection of Ho implies that there is a significant relationship between knowledge of the covid 19 prevention protocol in SDIT Al Madinah students and adherence to the covid 19 prevention protocol.

Knowledge plays an important role in determining complete behavior because knowledge will form beliefs which then in perceiving reality, provide a basis for decision making and determine behavior towards certain objects (Novita et al, 2018) so that it will affect a person's behavior. The decision that will be taken, because with knowledge someone has a basis for making choices (Prihantana et al, 2016).

Good knowledge of students and followed by adherence to the Covid 19 prevention protocol can be influenced by several factors, including parental knowledge about the understanding of Covid 19 which will have an impact on children's knowledge and understanding of the willingness to take steps to prevent Covid 19 disease. such as the habit of washing hands, so that children will automatically follow the habits of parents and environmental factors from schools that apply the Covid 19 prevention protocol (Notoatmodjo, 2010 and Rohita, 2021).

\section{CONCLUSION}

Knowledge of the Covid 19 prevention protocol for SDIT Al Madinah students, mostly 131 respondents $(70.8 \%)$ was good.

Compliance with the Covid 19 prevention protocol for SDIT Al Madinah students, mostly 168 respondents $(90.8 \%)$ were compliant.

There is a significant relationship between the knowledge of the covid 19 prevention protocol in SDIT Al Madinah students to the compliance of the covid 19 prevention protocol. 


\section{Journal Of Nursing Practice}

http://thejnp.org

ISSN: 2614-3488 (print); 2614-3496 (online)

Vol.5 No.1. October 2021. Page.89-93

\section{REFERENCES}

Dharma, K. (2011). Nursing Research Methodology, revised edition. Jakarta

Hendrawan, A. (2019). Description of the Knowledge Level of $\mathrm{Pt}^{\prime} \mathrm{X}^{\prime}$ Workers About Laws and Regulations on Occupational Health and Safety. Journal of the Pomegranate Hope, 6(2), 69-81. https://doi.org/10.31935/delima.v6i2.76

https://corona.kebumenkab.go.id/index.php/web/data_all. (2021). Downloaded January 27, 2021

Ministry of Health. (2020). Guidelines for preparing for COVID-19. Jakarta.

Mona, Nailul. (2020). The Concept of Isolation in Social Networks to Minimize Effects Contagious (Corona Virus Spread Case in Indonesia). Journal of Social Humanities Applied. Vol. 2 No.2. University of Indonesia : Creative Advertising Study Program Vocational Education

Mendes RI. (2020). Protocol for Village Volunteers Against COVID-19. Jakarta

Nursalam, S. (2013). "Practical Approach to Nursing Science Research Methodology." Jakarta: Salemba Medika.

Novita, et al. (2014). Knowledge Level About Pulmonary TB Affects Mask Use In the Rumkital Lung Room Dr. Ramelan Surabaya. Scientific Journal of Health. Vol 7. No. 12. Surabaya : STIKES Hang Tuah

Prihantana, et al. (2016). Relationship of Knowledge with Level of Adherence to Treatment Tuberculosis Patients In RSUD Dr. Soehadi Prijonegoro, Sragen. Journal of Pharmacy Science and Practical. Vo. 2. No. 1. Bhakti Mulia Health Polytechnic

Priyanto, Agus. (2018). Relationship between Knowledge Level and Preventive Behavior Diabetic Wound Recurrence. Journal of Nurses and Midwifery. Vol. 5 No. 3. Kediri : STIKES Ganesha Husada

Sari, D.P, and Atiqoh, N.S (2020) The Relationship Between Public Knowledge and Compliance with the Use of Masks as an Effort to Prevent Covid-19 Disease spit. Medical Records and Health Information, Faculty of Health, Duta University Nation

Sugiyono. (2016). Qualitative Quantitative Research Methods and R \& D. Bandung: Alfabeta.

Susilo, A., Rumende, CM, Pitoyo, CW, Santoso, WD, Yulianti, M., Sinto, R., Singh, G., Nainggolan, L., Nelwan, EJ, Khie, L., Widhani, A., Wijaya, E., Wicaksana, B., Maksum, M., Annisa, F., Jasirwan, OM, Yunihastuti, E., Handling, T., New, I., ... Cipto, R. (2020). Coronavirus Disease 2019: Review of Current Literature Coronavirus Disease 2019: Review of Current Literatures. Indonesian Journal of Internal Medicine, 7(1), 45-67.

Wawan, A and M. Dewi. (2010). Theory and Measurement of Knowledge, Attitudes, and Human Behavior. Yogyakarta: Nuha Medika

World Health Organization. (2020). Situation reports. : https://www.who.int/docs/defaultsource/coronaviruse/situation-reports/20200329sitrep-69-covid-19.pdf?sfvrsn=8d6620fa_8.

Wu, Y. C., Chen, C. S., \& Chan, Y. J. (2020). The outbreak of COVID-19: An overview. Journal of the Chinese Medical Association, 83(3), 217-220. https://doi.org/10.1097/JCMA.00000000 00000270 